przestrzegał Araszkiewicz można osłabić m.in. przez zintensyfikowanie badań nad kultura pedagogiczną (tu rola myśli pedagogicznej jest niepodważalna) i ich upowszechnieniem wśród środowisk nauczycielskich. Nasuwa się tutaj pewna dygresja wyniesiona $\mathrm{z}$ badań nad pedagogiką dwudziestolecia. W tamtych czasach badaniem dziejów myśli pedagogicznej parali się również nauczyciele, co było niewątpliwie skutkiem mniej instrumentalnego kształcenia. Dziś poza wąskim gronem historyków wychowania mało kto interesuje się tradycją pedagogiczną. A przecież „nauki historyczne przestają być wyłącznie wiedzą o zdarzeniach i instytucjach; stają się także wiedzą o mentalności ludzi działających w określonych epokach. Tak rozumiana wiedza historyczna lączy $\operatorname{się~z~antropologią~filozoficzną~jako~nauka~o~historycznym~rozwoju~istoty~człowieka~oraz~}$ z nowocześnie rozumianą historią kultury jako nauką o formach i strukturach ludzkiej działalności społecznej i o uczestnictwie ludzi w tym «ludzkim świecie»". Dzieje myśli pedagogicznej stanowią sedno tak pojętej nauki historycznej.

Należy oczekiwać, że dalszy rozwój historii wychowania potoczy się nowymi torami, gdzie badania nad myślą pedagogiczną uzyskają odpowiednią rangę równą roli jaką pełni myśl w kształtowaniu ludzkich postaw. Szansą dla niej może być Sekcja Historii Wychowania PTP i budzący się „ruch młodych historyków wychowania".

Postulaty końcowe:

1. Niezbędna jest integracja działań środowiska historyków wychowania (powstanie zespołów badawczych),

2. Dla prawidłowego rozwoju dyscypliny konieczną się wydaje intensyfikacja badań w zakresie historii myśli pedagogicznej (np. przez stworzenie Grupy Badawczej w ramach w/w SHW przy PTP),

3. Niezbędne jest rozszerzenie zasięgu pracy badawczej na środowiska nauczycielskie i współdzialanie z historykami myśli ped. poza granicami kraju (Wydział Nauk o Wychowaniu UZ nawiązał w tym celu kontakty z Uniwersytetami w Pradze i Brnie).

Dorota Żolądź

Poznań

\title{
Podróże edukacyjne XVI i XVII wieku - próba typologii
}

W okresie Renesansu znane już wcześniej podróże edukacyjne stały się nieodłącznym elementem kultury europejskiej. Podróżowała cała Europa w poszukiwaniu wiedzy, umiejętności, znajomości, ogłady itp. Ocena tego zjawiska już ówcześnie była niejednolita. Mimo głosów krytycznych jakie pojawiały się na łamach literatury staropolskiej również nasi rodacy wlączyli się w renesansową społeczność podróżujących.

Pod pojęciem „podróże edukacyjne" kryje się kilka rodzajów peregrynacji, chociaż nie zawsze można je jednoznacznie od siebie odróżnić. Termin „peregrinatio academica" - wędrówki akademickie - stosuje się często na określenie rozmaitych podróży. Nie ulega wątpliwości, że niezależnie ad nazwy, jaką określilibyśmy wszystkie te podróże, miały one generalnie jeden cel - zdobywanie wiedzy i umiejętności, różnie - w zależności od wielu czynników - rozumianych.

4 B. Suchodolski, tamże, s. 538.

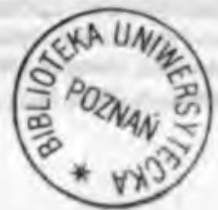


Polska literatura wydaje się być pod względem terminologii w tym zakresie stosunkowo uboga. Mówi się u nas więc o „wyjazdach na studia" i „wyjazdach w podróże naukowe”", wojażach

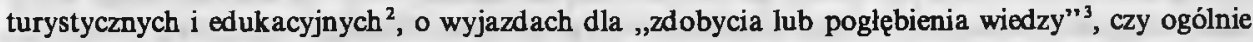
o ,podróżach zagranicznych" $\mathrm{z}$ uwzględnieniem ich rozmaitych aspektów - edukacji szkolnej i pozaszkolnej - „poznawanie nowych środowisk, nowych ludzi i urządzeń społeczno-politycznych"“. Wszystkie te określenia są nieścisłe i nie oddają istoty poszczególnych rodzajów podróży. Tym bardziej, że różnily się nie tylko podróże odbywane w jednym czasie, ale podlegały one zmianom na przestrzeni stuleci.

Pod tym względem literatura innych krajów jest bogatsza i precyzyjniejsza. Niemiecka nauka używa wielu terminów na określenie różnych rodzajów podróży edukacyjnych. Mamy więc do czynienia $\mathrm{z}$ terminem „Bildungsreisen” na określenie podróży podejmowanych dla zdobycia ogólnego poloru, orientacji w świecie, nawiązania stosunków; „Ausbildungsreisen" - podróże podejmowane w celu zdobycia wykształcenia poza ojczyzną $i$ „Fortbildungsreisen” mające na celu kontynuowanie ksztalcenia.

Powszechnie w literaturze używa się terminu „peregrinatio academica"s jako określającego podróże podejmowane $w$ celu odbycia nauki zagranica, przede wszystkim $w$ zagranicznych szkołach wyższych. Ten typ podróży wywodzi się powszechnie z czasów średniowiecza. Niektórzy łączą jego początki z powstaniem uniwersytetów oraz wskazuja, że były one u swego zarania swoistą odmianą pielgrzymek (peregrinatio religiosa). Zmianie uległ tylko cel podróży, którym w odróżnieniu od różnego rodzaju miejsc kultu w przypadku pielgrzymek, były szkoły wyższe - akademie i uniwersytety ${ }^{6}$.

W odróżnieniu od podróży tego rodzaju stosuje się termin „Le Grand Tour”, „Kavalierstour” (czy Kaveliersreise), czy ,il viaggio d'instruzione”, kiedy mowa jest o wojażach nastawionych na „pozaszkolny aspekt” peregrynacji i podejmowanych przez ludzi wywodzących się z bogatszych warstw społecznych, głównie magnatów, szlachtę, ewentualnie przedstawicieli bagatego patrycjatu miejskiego.

Niekiedy wyróżnia się jeszcze "Gelehrtenreisen", czyli podróże uczonych odbywane w podobnych celach - zdobycia i uzupełnienia wiedzy, nawiazania i podtrzymywania kontaktów itp.

W tym podziale nie ma zgodności i jasności do końca. Niekiedy jako wspólne określenie dla rozmaitych podróży podejmowanych w celu zdobycia wiedzy używano terminu "Grand Tour” i w ich ramach wyróżniono "Studienreisen”, podróże studyjne - rzeczywiste „peregrinatio academica”, „Bildungs- i Kaveliersreisen” - podróże edukacyjne i „Gelehrtenreisen” - podróże uczone. Przy czym najczęściej w jednej podróży łączono różne aspekty, np. "Grand Tour" arystokraty mogła być jednocześnie uczoną podróżą jego pedagoga. Jedyną metodą jest tutaj dokładna analiza źródeł. ${ }^{7}$

Podkreśla się również kolejność pojawiania się różnych odmian peregrynacji. Peregrinatio academica wywodzi się, jak wspomniano ze średniowiecza, natomiast „Grand Tour” pojawia się

' M. Pawlak, Studia uniwersyteckie mlndzieży z Prus Krslewskich w XVI-XVIII wieku, Torun 1988, s. 18-19.

${ }^{2}$ K. Targosz, Jana Sobieskiego nauki i peregrynacje, Wroclaw 1985, s. 52.

${ }^{3}$ H. Dziechcińska, Podróż - jej miejsce w twiadomosci spolecznej, Odrodzenie i Reformacja w Polsce, t. XXXIII, 1988, s. 28; tejże, $O$ staropolskich dziennikach podróży, Warszawa 1991 , s. 10.

4 Z. Zoladź, Idealy edukacyje daby staropolskiej, Warszawa 1990, s. 65 i n.

'H. de Ridder-Symoens, Tendances a méthodes de recherche nu la mobilité wniversitaire, w: Dall'Universitd degli Studenti all'Universitd degli Studi, Messina 1991, s. 27; tejże, Die Kavalierstour im 16. und 17. Jhr., w: Der Reisebericht, oprac. P. J. Brenner, Franlfurt/M 1989, s. 197.

- N. Conrads, Politische und staatsrechtliche Probleme der Kavalierstour, w: Reiseberichte als Quellen europäischen Kulturgeschichte, hg. v. A Mq̨czak, Wolfenbúttel 1982, s. 47; J. J. Berns, Peregrinatio academica und Kavalierstour. Bildungsreisem junger Deutscher in der Frühen Neuzeit, w: Rom-Paris-London. Erfahrung und Selbsterfahrung deutscher Schriftsteller und Kïantler in den fremden Metropolen, hrsg. v. C. Wiedemann, Stuttgart 1988, s. $155 \mathrm{i}$ in.

'H. de Ridder-Symoens, Die Kavalierstowr..., s. 204 - 205. 
później. Niekiedy wskazuje sį̨ drugą połowę XV, innym razem początek XVI wieku jako czasy powstania nowego typu podróży edukacyjnej. Wiązało się to $\mathrm{z}$ kształtowaniem się stanu szlacheckiego i nowych ideałów edukacyjnych. Peregrinatio academica to przede wszystkim studia na obcych wszechnicach, miały kształtować określony ideał człowieka - uczonego, humanistę. W okresie późniejszym nastawienie części społeczeństwa - głównie szlachty - uległo zmianie. Chociaż studia na uniwersytetach nadal w pewnym zakresie były uwzględniane przez szlacheckie programy edukacyjne, ale ich charakter się zmienił, przeszedł od zawodowego, w konkretnym fachu, do swoistej stanowej edukacji szlacheckiej. $Z$ programów uniwersyteckich wybierano elementy, które odpowiadały potrzebom szlachty i przygotowywały ją do późniejszej działalności. Uzupełniano to „ćwiczeniami”. Z biegiem czasu coraz większą rolę podczas tych podróży odgrywały powstające powszechnie w Europie Zachodniej akademie rycerskie", zaspokajające gusty arystokracji i bogatej szlachty i stąd często przez nią odwiedzane. Ważnymi etapami, czy wręcz punktami docelowymi podróży edukacyjnych szlachty były dwory władców europejskich. Wraz z ewolucją ideałów edukacyjnych zmieniły się również kierunki peregrynacji. Najbardziej popularne w okresie Renesansu Włochy musiały ustąpić miejsca Francji, Niderlandom, czy Anglii.

Spróbujmy dotychczasowe rozważania zreasumować i znaleźć polskie terminy na określenie poszczególnych rodzajów podróży. Mamy więc do czynienia z dwoma rodzajami podróży:

1. Podróże, których celem była nauka w obcych szkołach. Wybierający się w taką podróż młody człowiek miał określony cel - konkretną szkołę (lub szkoły), najczęściej, chociaż nie zawsze, chodziło o szkołe wyższą - uniwersytet lub akademię przyciągającą poziomem nauki lub sławą profesorów - można określić je mianem „peregrinatio academica”, czy polskim odpowiednikiem wędrówek akademickich, podróży na studia, podróży naukowych. W tym przypadku nie ważna była sama podróż, ona tylko służyła istotniejszemu celowi, jakim była nauka w konkretnych ośrodkach uniwersyteckich. Z polskich podróży wyróżnić tutaj trzeba wszystkie te, których celem był pobyt i nauka w zagranicznych ośrodkach uniwersyteckich.

2. Różniące się celem od pierwszego rodzaju podróże podejmowane dla poznania świata i ludzi, obcych obyczajów i kultur, obcych języków itp. Typ ten miał wiele wspólnego z podróżami, które określilibyśmy dzisiaj mianem turystycznych - tutaj odpowiednia byłaby nazwa "Grand Tour", czy podróży edukacyjnych. Dla tego rodzaju istotna była sama pdróż, podczas której zwiedzano, oglądano, poznawano. Ruchliwość, przenoszenie się z miejsca na miejsce, a nie pozostawanie $w$ jednym, to podstawowa cecha tego zjawiska. W jednym $z$ angielskich źródeł $z$ tego okresu określono je trafnie jako „movie academy, or the true peripatetic schol". To sama podróż miała znaczenie edukacyjne, ksztaltujące młodego człowieka, dostarczała mu wiadomości i umiejętności. Niekiedy opuszczano ojczyznę na kilka lat, by poza jej granicami zdobywać niezbędne w myśl poglądów szlacheckich w przyszłym życiu i działalności umiejętności. Nasilenie tego typu podróży przypadło na schyłek XVI i pierwszą połowę XVII wieku.

W tym typie znajdą się liczne podróże szlachty i magnaterii XVI i XVII wieku, których ślady znajdujemy również $w$ uniwersyteckich metrykach. Jeżeli nazwisko jednej osoby znajdujemy w kilku księgach wpisów, a odległości czasowe między tymi wpisami są niewielkie, oznacza to raczej, że osoba ta „peregrynowała”, a nie studiowała i jej wpis w księdze immatrykulacyjnej, to ślad podróży a nie nauki. Podczas takich podróży szlachta i magnateria odwiedzała również obce dwory, akademie rycerskie, przebywała w obozach wojskowych, niekiedy uczestniczyła w walkach poznając sztukę wojenną, ale przeda wszystkim podróżowała i poznawała. Miejsce dawnego modelu człowieka - wykształconego humanisty zajmuje obyty $\mathrm{w}$ świecie dworzanin (honnête homme, Hofmann, gentleman).

Często możemy mówić o typie pośrednim łączącym w sobie elementy obu wyróżnionych - nauka w szkole uzupelniona edukacją poza nia - zwiedzaniem, poznawaniem... Niekiedy mamy

' N. Conrads, Ritterakademien der frühen Neuzeit. Bildungs als Standesprivileg im 16. und 17. Jahrhundert, Göttingen 1982. 
do czynienia $\mathrm{z}$ innym rodzajem łączenia różnych typów $\mathrm{i}$ aspektów podróży. Wspomniano już o tym wyżej - mianowicie ta sama podróż podejmowana przez kilka osób, miała dla każdej z nich inny charakter. Centralną osobą był naturalnie szlachcic lub magnat, w jego interesie podróż podejmowano i cała była jemu podporządkowana. $\mathrm{Z}$ jego punktu widzenia mogła ona mieć charakter podróży edukacyjnej szeroko rozumianej, uwzględniającej również aspekty podróży naukowej. Młodzieniec słuchał wykładów uniwersyteckich, ale przede wszystkim korzystał $\mathrm{z}$ innego aspektu podróży - poznawał, zwiedzał, brał prywatne lekcje z różnych nauk itp. Jego preceptor natomiast, obok swoich obowiązków polegających na czuwaniu nad powierzonym mu młodzieńcem, wpisywał się na uniwersytet i poszerzał $w$ ten sposób swoją wiedzę, niekiedy zdobywając stopnie naukowe - dla niego była to więc głównie podróż naukowa.

Innym przypadkiem jest wzajemne uzupełnianie się tych podróży. Młody człowiek najpierw wyjeżdżał za granicę, by uczyć się w którejś z tamtejszych szkół. Potem na jakiś czas powracał do domu i po kilku latach wyjeżdżał ponownie, tym razem już w podróż edukacyjną. Takie łączenie różnych podróży polecała staropolska teoria pedagogiczna. Na przykład Hieronim Baliński w traktacie „De educatione pueri” zalecał by młodzieńca dwa razy wysłać do cudzych krajów. Gdy skończy dwanaście lat, po raz pierwszy, na dwa albo trzy lata. Baliński polecał ziemie niemieckie, chociaż dostrzegał ich wady - „wszystko w Niemczech przygrubszym (prymitywne, prostackie), ale ... potem się to we Włoszech wypoleruje". Przerwa w podróży powinna trwać okolo roku, w trakcie którego młody człowiek miał poznawać polskie prawa - „leges patrias dać mu w ręce i już wczas mu informacyje gotować i informować go, ile będzie przez ten czas mogło być w nich, ne sit hospes in patria (aby nie był obcym w ojczyźnie)", przypatrywać się obradom sejmu - „przy kim przypatrując i przysłuchując ludziom, zwyczajom, rzeczom i sprawom, gdyż też tam legum executia bywa", poznawać dwór. Około piętnastego roku życia powinien ponownie wyjechać. Tym razem celem mają być Włochy, miał tam być dwa lata „aby i pierwsze studia przepolerował i exercitia graviora capescat, których tam wszytkich barzo dobrze uczą, jako kawalkatury, szermierstwa, skoków, muzyki, turniejów ze wszytkich miar i broni, na koniu jako której używać"?.

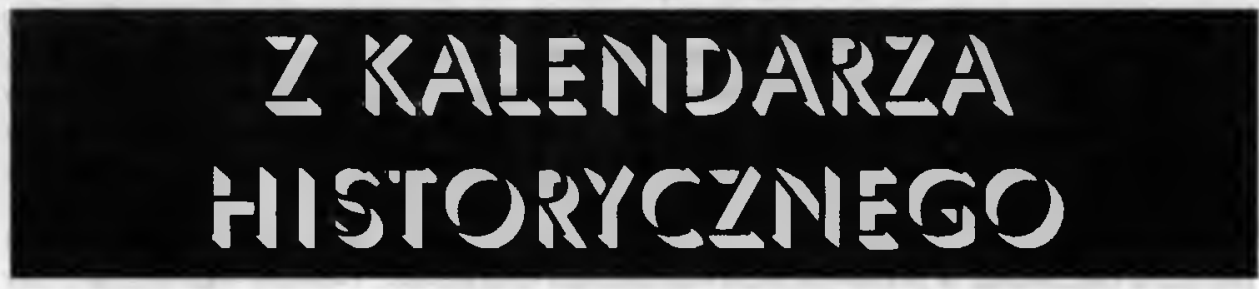

Wiesław Jamrożek

Poznań

\section{Uniwersytet Wakacyjny w Zakopanem}

W bieżącym roku kalendarzowym mija 90 lat od uruchomienia w Zakopanem Wyższych Kursów Wakacyjnych, zwanych również Uniwersytetem Wakacyjnym. Myśl powolania do życia adrębnego stowarzyszenia, którego zadaniem miało być utworzenie instytucji - jak to później

'H. Baliniski, De educatione pueri nobilis, w: Pisma pedagngiczne polkkiego Odrodzenia, oprac. J. Skoczek, Wroclaw 1956, s $374 \mathrm{i}$. 